\title{
Recycled chopped rice straw-cement bricks: an analytical and economical study
}

\author{
M. Allam \& G. Garas \\ Civil Engineering Department, National Research Centre, Egypt
}

\begin{abstract}
The Egyptian rice yield is one of the highest in the world (9.1 tons per hectare in 2001), a crop that leaves behind roughly 4.0 million tons of straw annually. Because of limited water resources, the government of Egypt has tried to limit rice cultivation. However, cultivation has continued to expand due to rice production's high profits. The methods for disposing of the straw and stubble residue remaining in the fields after harvest are either burning or baling. Although some limited uses of rice straw, such as for animal feed or paper making, are maintained, burning is still the principal disposal method for most of the rice straw residue, as it is efficient, effective and cheap, even after being phased out in the Egyptian law of Environment number 4-1994. As a result most farmers tend to burn the straw in open fields, boosting air pollution and serious human health problems due to the emission of carbon monoxide.

This paper addresses the recycling of chopped rice straw to produce light weight cement bricks to be used as fillers in skeleton type buildings. The production of these bricks was studied analytically to reach the best mix proportions under compression strength not less than $80 \mathrm{~kg} / \mathrm{cm}^{2}$ according to the Egyptian codes of building. An economical market study for the mass production of the cement brick has been carried out.

It was concluded that the rice straw-cement brick that would maintain a compression stress up to $115 \mathrm{~kg} / \mathrm{cm} 2$ costs $25 \%$ less than the similar pure cement brick available in the market.

Keywords: cements brick, agricultural wastes recycling, chopped rice straw, cement composites.
\end{abstract}




\section{Introduction}

\subsection{Building in ancient Egypt}

\subsubsection{Mud}

The absence of rain, the scarcity of wood and an abundance of sunshine made adobe the preferred building material. Loamy Nile mud mixed with straw resulted in surprisingly strong bricks. A sun baked mud brick without straw had a strength of less than $6 \mathrm{kp} / \mathrm{cm}^{2}$; the addition of straw resulted in a brick three times as strong (about $20 \mathrm{kp} / \mathrm{cm}^{2}$ ). In every location during a building project, brick moulds of equal size were used, which were between about 30 to $45 \mathrm{~cm}$ in length and 15 to $20 \mathrm{~cm}$ in width. The brick size was thus standardized. At Karnak the bricks measured 40 by 20 by 15 and in the Late Period Naukratis they were about the same size. These dimensions suggest that they were generally laid in cross bond. A modern mud brick maker can produce between 1000 and 2000 bricks a day. Five days' work should therefore suffice to make about 5000 bricks, which is the amount needed for a worker's one storey house of 60 to $80 \mathrm{~m}^{2}$ with $40 \mathrm{~cm}$ thick walls. Few ancient mud bricks survived, but of those that did, some can be dated because they were frequently stamped with the cartouche of the reigning monarch [3]. Given the scarcity of fuel, the Egyptians rarely used burned bricks [4].

\subsubsection{Mortar}

The ancient Egyptians did not know of the hard setting lime plaster invented by the Greeks, but used instead a mixture of gypsum and quartz with small amounts of lime. This was not as disastrous in the dry climate of Egypt as it would have been under wetter conditions [5].

\subsection{The use of natural materials in building}

Around the world, masonry is the preferred material of construction for housing. Concrete masonry is ideal for residential buildings of many types, in different heights and in diverse geographical areas. Concrete masonry is selected by builders desiring to provide economical, comfortable housing for residents. Residents appreciate the many properties of concrete masonry that provide comfort and safety. The most notable properties are fire resistance and low sound transmission [1].

Sustainability is one of the main focuses of the recent international housing development strategies. Since the 1950's Egypt has adopted several low-cost housing strategies, in an effort to compensate for growing housing demands. At present, vast majority of housing units are reinforced concrete structures with either bricks or cement block infill, which are adopted materials from other climatic zones and countries with different types of natural resources. One of the most abandoned materials in Egypt is cellulous non-wood fibrous materials, such as rice straw. Instead of burning the straw, recycling it with a mixture of cement forms a sustainable low cost building material, which also reduces atmospheric 
pollution. In addition to these benefits, the straw could act as a thermal insulation material for the unpleasant Egyptian weather. The use of thermal insulation helps reduce energy costs, while creating pleasant indoor temperatures [2].

Akmal conducted a preliminary simple laboratory study on preparing and examining the compression stress on several mix proportions to produce a strawcement brick to be used as a filling block in the skeleton traditional building technique [6].

\section{Research significance}

Rice is one of the major field crops in Egypt. The rice cultivation area in Egypt was approximately 1.4 million feddan which is about $16 \%$ of Egypt's total cultivated area during the summer season, but recently this area increased to 1.9 million feddan according to the latest Agricultural Ministry announcement. This increase resulted in huge amounts of rice straw as an agricultural residue - about 4 million tons annually - which are highly accused as the most environmental pollutant in Egypt. Although great attempts have been made to use this residue in different industrial needs, yet the remaining amounts tend to cause great problem to the Egyptian Government due to its burning which was phased out in the Egyptian law of Environment number 4-1994 [9]. Recycling rice straw to be used in building process is one of the highly encouraged research areas that would yield great solutions to this major environmental problem.

The present study is based on developing a simple procedure to produce, examine and economically evaluate a straw-cement brick on the mass production scale that would act as a multifunctional building unit in low-cost buildings. The brick is also aimed to serve as a high insulator in arid desert areas.

\section{Methodology of sample preparation}

\subsection{Materials used}

Cement Brick Technology can be easily adapted to suit special needs of users by modifying design parameters such as mix proportion, water/cement ratio and types of additives. The bricks used herein were produced using a mobile semimechanized egg-laying machine with vibrator and steel manual moulds. The common brick size is $25 \times 12 \times 6 \mathrm{~cm}$. These units are made of cementitious mixes that are placed into steel moulds, vibrated and compacted, then demoulded and cured. The materials used were:

1- Ordinary Portland cement (OPC) from local market.

2- Fine aggregate siliceous sand with a maximum size of $5 \mathrm{~mm}$, well graded and free from impurities.

3- Coarse aggregate free of impurities with nominal maximum of size of $10 \mathrm{~mm}$.

4- Chopped straw with a length ranging $1.5-2.5 \mathrm{~cm}$.

5- Natural fresh drinking water free of impurities. 
Table 1: $\quad$ Mix proportions of rice straw-cement bricks.

\begin{tabular}{|c|c|c|c|c|}
\hline $\begin{array}{c}\text { Type of } \\
\text { Mix }\end{array}$ & $\begin{array}{c}\text { Fine } \\
\text { Aggregate } \\
\left(\mathrm{m}^{3}\right)\end{array}$ & $\begin{array}{c}\text { Coarse } \\
\text { Aggregate } \\
\left(\mathrm{m}^{3}\right)\end{array}$ & $\begin{array}{c}\text { Chopped } \\
\text { Rice Straw } \\
(\mathrm{Kg})\end{array}$ & $\begin{array}{c}\text { Cement } \\
(\mathrm{Kg})\end{array}$ \\
\hline Mix (A) & 0.9 & 0.9 & 40 & 400 \\
\hline Mix (B) & 0.85 & 0.4 & 70 & 400 \\
\hline Mix (C) & 0.85 & 0.2 & 90 & 400 \\
\hline
\end{tabular}

\subsection{Testing objectives}

The objective of this research was first to study the effect of using different percentages of chopped rice straw in different brick mixes for the purpose of optimizing the compressive strength. The next stage of the experimental program was done in order to compare the chopped rice straw-cement bricks produced with the local market cement bricks from the economical point of view.

\subsection{Parameters}

The main parameters considered in preparing and testing the 3 mixes in this study were: rice straw content and the ratio between coarse and fine aggregate. The brick mixes are presented in Table 1.

\subsection{Sample casting and curing}

Coarse and fine aggregates were batched by volume using wooden boxes with the desired volume. Cement was added by weight using only whole bags of 50 $\mathrm{kg}$ to ensure uniform proportions of mix. The chopped rice straw was added to the mixture according to the previously mentioned quantities. The dry mixes were batched outdoors in rotating power-driven resolving mixer of 100 litres capacity before adding water. Then the bricks were moulded and vibrated using 'egg-laying' mobile machines and then de-moulded immediately after compaction. The samples were carried away on pallets to the curing place and they were regularly sprayed with water twice a day for a period of 7 days to gain sufficient strength. From visual inspection, it was clear that mix $\mathrm{C}$ with the highest straw content $90 \mathrm{~kg}$ was non-consistent. Accordingly, bricks of mix C were excluded.

\section{Laboratory testing}

\subsection{Brick measurements}

For each mix of the rice-straw cement bricks A and B, 3 samples were tested in the laboratory. In addition, 3 samples of a standard commercial cement brick (Techno Crete Brick) were tested to compare the compression stress of each brick. The dimensions of bricks for each sample tested were checked out for 
Table 2: $\quad$ Dimensions of brick samples tested.

\begin{tabular}{|c|c|c|c|c|}
\hline \multirow{3}{*}{ MIX } & \multirow{4}{|c|}{ SAMPLE } & \multicolumn{4}{|c|}{ DIMENSIONS } & \multicolumn{2}{c|}{ IN } \\
\hline & & LENGTH & WIDTH & HEIGHT \\
\cline { 2 - 5 } & 1 & 25.5 & 12.0 & 5.9 \\
\cline { 2 - 5 } MIX A & 2 & 25.7 & 12.0 & 6.0 \\
\cline { 2 - 5 } & 3 & 25.9 & 11.9 & 6.0 \\
\hline \multirow{3}{*}{ MIX B } & 1 & 26 & 11.8 & 6.0 \\
\cline { 2 - 5 } & 2 & 25.5 & 11.9 & 6.1 \\
\cline { 2 - 5 } & 3 & 25.5 & 12.0 & 6.0 \\
\cline { 2 - 5 } & 1 & 25.5 & 11.9 & 6.0 \\
\hline \multirow{3}{*}{\begin{tabular}{c} 
Sample \\
\cline { 2 - 5 }
\end{tabular}} & 2 & 25.7 & 12.0 & 5.9 \\
\hline
\end{tabular}

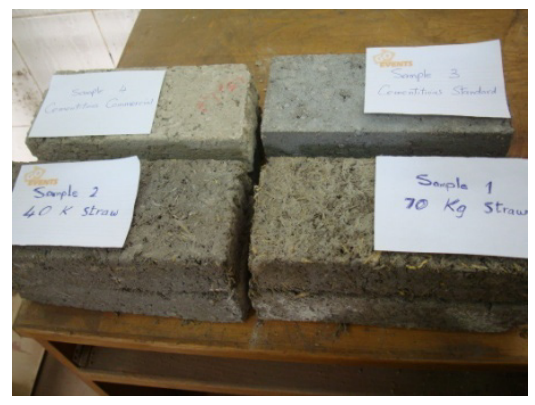

Figure 1: $\quad$ Samples under testing.

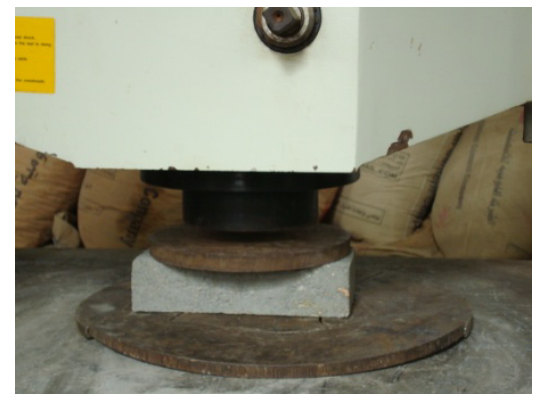

Figure 2: $\quad$ Specimen testing.

conformance to the size and readability requirements according to the ASTM Standards [7] on which the work was based as follows: C67-07a, C1093-07, and E4-07 and the readings were listed in Table 2.

\subsection{Compression test apparatus}

Apparatus used in making compressive strength tests of bricks include the compression machine in which specimens are tested and the bearing plates used in testing the specimens when the bearing blocks are not of a suitable size. The Shumadsu $1000 \mathrm{KN}$ universal tension- compression machine was used in testing the bricks for compression. The machine is equipped with a data analyzing output unit for output data recording. 
Table 3: $\quad$ Compression test results.

\begin{tabular}{|c|c|c|c|}
\hline MIX & $\begin{array}{c}\text { Specimen } \\
\text { No. }\end{array}$ & Max. load (Ton) & $\begin{array}{c}\text { Max. Stress } \\
\left(\mathrm{Kg} / \mathrm{Cm}^{2}\right)\end{array}$ \\
\hline \multirow{3}{*}{ MIX A } & 1 & 35 & 114.4 \\
& 2 & 36 & 116.7 \\
& 3 & 35 & 113.6 \\
\hline \multirow{3}{*}{ MIX B } & 1 & 30 & 97.8 \\
& 2 & 22 & 72.5 \\
\hline & 3 & 15 & 49 \\
Commercial & 1 & 54 & 177.9 \\
Sample & 2 & 63 & 204.3 \\
& 3 & 55 & 177.6 \\
\hline
\end{tabular}

\subsection{Testing procedure}

The 3 rice-straw bricks under testing were prepared and compared with a standard pure cement commercial brick (Techno-Crete Brick) as shown in Fig. 1. After measuring and recording dimensions of each specimen, bricks were placed, one by one, flat wise on the platen of the testing machine. A $0.5 \mathrm{~mm} / \mathrm{sec}$ rate of loading was applied on each specimen until failure observation and recording the maximum load as shown in Fig. 2.

\subsection{Test results and their analysis}

The results of compression testing for all mixes are summarized in Table 3. The compressive stress results were compared to the values specified by the Egyptian Code of Practice ECOP 204-2005 which states that the stress of bricks should not be less than $80 \mathrm{~kg} / \mathrm{cm}^{2}$ for red mud bricks [8].

The maximum compression loads applied on the three mixes showed wide variance and resulted in different compressive stress values. The specimens of mix (B) containing $70 \mathrm{~kg} / 1000$ brick of chopped rice straw, showed non homogeneity in its maximum compressive stress values $97.8,72.5$ and 49.0 $\mathrm{kg} / \mathrm{cm}^{2}$ for samples 1,2 and 3 respectively. These values are considered to be relatively low according to the specified values stated by the Egyptian Code of Practice ECOP 204-2005. This can be due to the partial loss of bond among the mix components as a result of the excessive amount of chopped straw existing in the mix.

The maximum compressive stress values for specimens of mix (A) increased by decreasing the chopped rice straw content to a value of $40 \mathrm{~kg} / 1000$ bricks using the same quantity of cement with almost the same amount of fine aggregate. The maximum compressive stress values for mix (A) were 114.4, 116.7 and $113.6 \mathrm{~kg} / \mathrm{cm}^{2}$ for samples 1,2 and 3 respectively showing homogeneity in its results. These values exceeded the $80 \mathrm{~kg} / \mathrm{cm}^{2}$ specified by the Egyptian Code of Practice ECOP 204-2005. These results are considered 
Table 4: Comparison between commercial cement and rice-straw brick.

\begin{tabular}{|c|c|c|}
\hline Brick Type & $\begin{array}{c}\text { Average Compressive } \\
\text { Stress } \mathrm{Kg} / \mathrm{cm}^{2}\end{array}$ & $\begin{array}{c}\text { Price } / 1000 \text { Bricks } \\
\text { L.E }\end{array}$ \\
\hline $\begin{array}{c}\text { Commercial Standard } \\
\text { Brick }\end{array}$ & 186 & 500 \\
\hline $\begin{array}{c}\text { Rice straw-cement brick } \\
\text { Type A }\end{array}$ & 115 & 380 \\
\hline
\end{tabular}

relatively higher than the values obtained in Garas et al. [10], which reached stresses of $36.6 \mathrm{~kg} / \mathrm{cm}^{2}$ for the same mix A proportions produced by a different supplier. This could be due to the lack of quality control measures and inadequate curing time. Standard commercial samples obtained from the local market were considered to be very homogeneous with maximum compressive stress values of $177.9,204.3$ and $177.6 \mathrm{~kg} / \mathrm{cm}^{2}$ for samples 1,2 and 3 respectively.

\section{Economical study}

Cost is the basic and starting point of any construction industry. One of the main elements for this industry is brick manufacturing and its cost. In carrying out cost comparison, it should not be based only on the production cost per brick; Utilization cost for comparative purposes should include also the indirect costs. Average Compression Test Results as well as Price Comparison are summarized in Table 4.

Table 4 shows that the use of chopped rice straw- cement bricks for wall bearing construction system will result in savings of $25 \%$ of the total direct cost per square meter of wall when compared to the commercial standard $25 \times 12 \times 6$ $\mathrm{cm}$ cement bricks. This direct saving in costs is added to the environmental profit of reducing quantities of an undesirable agricultural byproduct that is traditionally burnt by farmers in open fields, boosting air pollution and serious human health problems due to the emission of carbon monoxide.

Besides, rice straw material is known for its high insulation properties which could add another indirect saving value by minimizing usage of air conditions and heaters.

Based on this analysis, bricks made from chopped rice straw and cement is being recommended for building construction in Egypt.

\section{Conclusions}

The following conclusions can be drawn from this study:

1- In Egypt, where rice is one of the major crops, open burning of rice straw after harvesting releases a large amount of air pollutants, which can cause harmful effects on the ambient air quality, public health and climate. 
Instead, a new chopped rice straw- cement brick was developed to overcome portion of this problem by recycling rice straw and incorporate it into building material.

2-Addition of $90 \mathrm{~kg}$ of chopped rice straw per quantities of materials required to produce 1000 bricks $(25 \times 12 \times 6 \mathrm{~cm})$ adversely affects the bond strength of the bricks produced. It was noticed that after 7 days curing time, the bricks seem to be very week and need additional time for curing and setting.

3- Optimizing the amount of chopped rice straw to $40 \mathrm{~kg} / 1000$ brick gives a maximum compressive stress of $115 \mathrm{~kg} / \mathrm{cm}^{2}$ which is considered to be reasonably adequate for building purposes. In addition, the bricks' curing period does not exceed 7 days.

4- An economical comparative study on the available standard cement bricks existed on the local market showed that saving up to $25 \%$ could be achieved by using chopped rice straw- bricks instead.

5- High insulation properties of rice straw adds another indirect cost saving value for using chopped rice straw- brick instead of traditional local market product.

\section{References}

[1] Graham, C.W., Take home-Contemporary Housing Productions: Housing and Practice COSC 662, Housing Construction \& Construction Material Innovations.

[2] Mansour, A., Srebric, J. and Burley, B.J. , Development of Straw-cement Composite Sustainable Building Material for Low-cost Housing in Egypt, J. Appl. Sci. Res., 3(11): 1571-1580,2007.

[3] Bagnall, R.S. \& Bruce, W Frier., The Demography of Roman Egypt, Cambridge University Press, 1994.

[4] Bard, Katheryn. A., Encyclopedia of the Archaeology of Ancient Egypt, Routledge, 1999.

[5] Building in Ancient Egypt, an article cited in: http://www.reshafim.org.il/ad/egypt/building

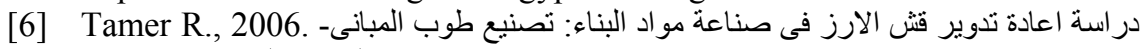
الجامعة الحديثة_قسم عمارة

[7] ASTM Standards, C67-07a, C1093-07, and E4-07.

[8] The Egyptian Code of Practice ECOP 204-2005, Ministry of housing and urban communities, 2005.

[9] The Egyptian law of Environment number 4 -1994.

[10] Garas, G., ELKady, H. and El Alfy, A., Developing A New Combined Structural Roofing System Of Domes And Vaults Supported By Cementitious Straw Bricks, ARPN Journal of Engineering and Applied Sciences, under publication, 2010. 